\title{
APPLICATION OF SEMANTIC TECHNOLOGY FOR CALCULATION OF WELDING TIME IN THE DEVELOPMENT OF NEW PRODUCTS
}

\author{
Ambrož Stropnik, Tomaž Vuherer, Ivan Samarď̌ić, Milan Zorman
}

Preliminary communication

Determining the time of execution is very important in the early stages of each project (e.g. making offers, design phase etc.), especially in the stage of planning. This paper presents our approach to estimating the welding time for the purposes of planning the manufacturing processes. The approach is based on the knowledge of welding experts from the Nieros metal d.o.o. company and standards of welding (international and internal). An expert system was developed based on semantic web technologies for calculating the welding time in the product design phase and it is strongly integrated with the main ERP system of the Nieros metal d.o.o. company. Test results are presented at the end of this article.

Keywords: expert system; new product development; ontology; welding of steels

Primjena semantičke tehnologije za izračun vremena zavarivanja u razvoju novih proizvoda

Prethodno priopćenje

Određivanju vremena izvršenja je vrlo važno u ranim fazama svakog projekta (npr. ponude, dizajn faza, itd.), a posebno u fazi planiranja. Ovaj rad predstavlja naš pristup procjeni vremena zavarivanja u svrhu planiranja proizvodnog procesa. Pristup se temelji na znanju stručnjaka za zavarivanje iz društva Nieros metala d.o.o. i na standardu za zavarivanje (međunarodni i unutarnji). Ekspertni sustav je razvijen na temelju semantičkih tehnologija za izračunavanje vremena zavarivanja u fazi projektiranja proizvoda. Sistem je snažno integriran sa glavnim ERP sustavom društva Nieros metala d.o.o. Rezultati eksperimenta su prikazani na kraju ovog članka.

Ključne riječi: ekspertni sustav; ontologija; razvoj novih proizvoda; zavarivanje čelika

\section{Introduction}

Manufacturing production planning is one of the most challenging tasks. Particularly challenging is the production planning for new products. The success (product performance) of most new products is determined in the product development phase, therefore it is very important to accurately design the product. Prior to the implementation of our expert system, the end number of welds on WPS document was usually unknown and they were marked as "n". Supported by our expert system the end number of welds can be determined only by adding required parameters; required welds are also visible on WPS document. Thus, the technological times are easily determined and the production is much more accurately planned.

The article focuses on a small segment of production planning and calculating the welding time of two metal sheets.

Primary purpose of this paper is to present the technological solution for calculating the welding time as the basic technological platform for developing of a complete solution upgrade to a new product (i.e. enterprise knowledge portal).

Great advantage of the proposed solutions is to invent the know-how and give the possibility to use expert knowledge through this software solution to all employees in the company. As a result, the efforts of human determining of welding time are reduced to minimum. Moreover, the verifiability of the calculations in such system is quite simple.

The innovation of our approach is most evident in two segments. The first is the implementation of an appropriate knowledge base for the purposes of calculating the welding time with Semantic Web technologies. This is the most significant method for generating rules for calculating the welding time which slightly deviates from the recommended welding standards. The second one is adaptation of the standard approach for calculating the welding time for production planning.

Chapter 2 presents different approaches of using expert systems in the manufacturing production planning processes. Chapter 3 presents the proposed approach of using expert systems for calculating the welding time based on the Semantic Web Technologies. Chapter 4 presents the application of the proposed approach in a Slovenian company Nieros metal d.o.o.. Further, user perspective and architecture of the entire system is presented. Chapter 5 describes the results of the experiment using implemented expert system in the Nieros metal d.o.o. company from the content point of view. In addition, results from the experiment are also presented. Chapter 6 concludes the paper with the discussion of advantages and disadvantages of the proposed approach, including further development of the proposed method.

\section{Background and related work}

Expert systems were first developed in 1960s to deal with complex problems in medicine. MYCIN and DENDRAL were the first developed Expert Systems [1]. Later on, many expert systems were developed, primarily for research purposes of medical diagnoses, electronics and transportation management. Only few were developed for the needs of production (e.g. welding).

New technological opportunities for the development of expert systems emerged with the development of internet. The use of expert systems gained a new meaning in connection with Semantic Web and semantic technologies [2][3][4][5]. 
At the same time, new theoretical classifications of expert systems turned up: The Static / Dynamic and Internet-based expert systems [3][4][6]. In the field of welding and new product development, several expert systems already exist:

Tsoukalas and others present the application of an expert system for aluminium welding - WELDES. The WELDES system is to be used as an industrial tool for the identification, assessment, and correction of aluminium welding defects. The system consists of two modules: The Diagnostic Module and the Adviser Module [7].

Lin and Harding present MSE (manufacturing system engineering) ontology model for supporting information autonomy that allows the individual team member to keep their own preferred languages or information models rather than requiring them all to adopt standardized terminology [8].

Chen and others present a unique mechanism for integrating ontology-based product lifecycle knowledge for effective integration of heterogeneous product knowledge, distributed among different enterprises during a product's lifecycle, thereby facilitating sharing of this product knowledge [9].

Panetto and others present their approach for facilitating systems interoperability in a manufacturing environment, based on the postulate that an ontological model of a product may be considered as a facilitator for interoperating all application software that share information during the physical product lifecycle [10].

Baloh and others present the pilot knowledge portal based on semantic web technologies for supporting a new product development in Slovenian white goods company Gorenje d.d. [11].

Urrea and others present their approach to development of an expert system for the selection of materials to be used in the construction of the main structure of a crane-like device for transporting persons with physical disabilities. The proposed method includes a stage in which the theory of the characteristics of the materials was used and another one that involves solely computational development with the application of fuzzy $\operatorname{logic}[12]$.

Janasekaran and others present their approach of fuzzy logic-based prediction model for fracture force using low-power fiber laser beam welding. They build an intelligent fuzzy expert system model to predict the fracture force of the joint at laser beam welding process. The fuzzy expert system is based on the Mamdani technique and is implemented in MATLAB R2009b [13].

The abovementioned approaches deal with similar challenges, but cannot be used as a solution in our case.

\section{Approach and methodology}

Our method for calculating welding time consists of five steps (Fig. 1) and uses the following data:

- Thickness of metal (thickness of material A, thickness of material B)

- $\quad$ Type of weld (i.e. S-I; pipes are not supported)

- Length of weld

- Position of welding (value is determined by welding experts of the Nieros metal d.o.o.)
- Technology of welding (only TIG technology is supported at the moment).

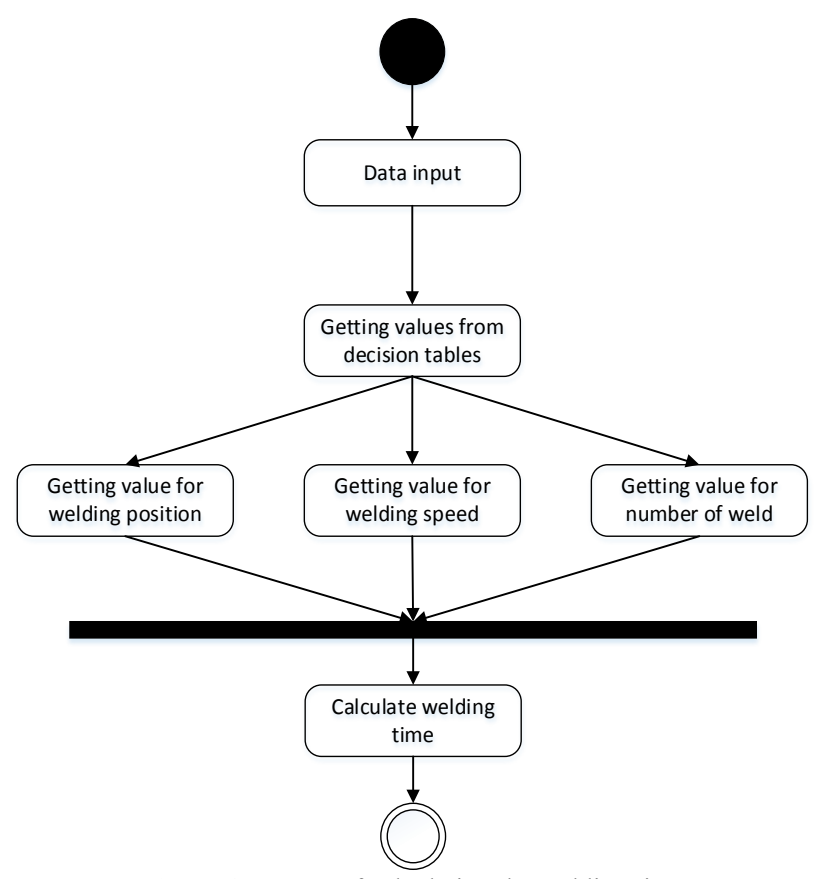

Figure 1 Process of calculating the welding time

In the first step, basic data adequacy is verified: the thickness of the base material and the type of weld. Second step acquired values from decision tables. Values for welding position, welding speed and for number of welds are parallel acquired from decision tables. The last step puts it all together in a mathematical formula described in chapter 3.2. The result is the welding time in minutes.

\subsection{Decision tables}

Decision tables represent the core of our method. They are based on thickness of material data (both for A and B material) and are very similar to tables proposed by the welding standards. The main difference between both types of tables is the listed values. They are different and determined by welding experts of the Nieros metal d.o.o. and, most importantly, based on their experiences and work process.

However, there are three basic decision tables proposed by our method:

- Decision table for checking the type of weld (i.e. if it is possible to weld metal with thickness $X$ and $Y$ with "S-I" type of weld?)

- Decision table for speed of welding

- Decision table for number of welds.

Each type of weld (i.e. the type of weld "with-I") has its own set of decision tables for the calculation of welding speed and the number of welds.

All decision tables are mapped to decision rules. Decision rules have the following general form:

If $\mathrm{A}$ and $\mathrm{B}$ and $\mathrm{C}$ then $\mathrm{D}$.

In the present case, decision tables are mapped to the rules:

If A (thickness of metal sheet) and B (thickness of metal sheet) and C (type of weld) then $\mathrm{D}$ (value). 
Table 1 Example of decision table for one type of weld

\begin{tabular}{|c|c|c|c|c|c|}
\hline \multicolumn{7}{|c|}{ Type of weld (e.g. S-I) } \\
\hline & \multicolumn{5}{|c|}{ Thickness of metal sheet of base material B } \\
(mm)
\end{tabular}

There are some other decision tables used for generating the draft WPS (Welding Procedure Specification) document. In our method for the calculation of welding time, they are used indirectly:

- Welding current

- Gas flow

- Diameter of the electrodes

- Diameter of the nozzle

- Diameter of the filler material

- Gas

- Voltages.

Some of them are generated using specific rules (left column in Tabs. $2 \div 5$ presents a value of decision table cell):

Table 2 Decision table of welding speed

\begin{tabular}{|c|c|}
\hline Welding current $(\mathrm{A})$ & Welding speed $(\mathrm{cm} / \mathrm{min})$ \\
\hline $1 \div 37$ & 9 \\
\hline $38 \div 70$ & 8 \\
\hline $71 \div 91$ & 7 \\
\hline $92 \div 130$ & 6 \\
\hline $131 \div 180$ & 5 \\
\hline $181 \div 300$ & 4 \\
\hline
\end{tabular}

Table 3 Decision table of the nozzle diameter

\begin{tabular}{|c|c|}
\hline Diameter of the electrodes $(\mathrm{mm})$ & Value $(\mathrm{mm})$ \\
\hline 1,6 & $4 \div 6$ \\
\hline 2,4 & $6 \div 8$ \\
\hline 3,2 & $8 \div 10$ \\
\hline
\end{tabular}

Table 4 Diameter of filler material

\begin{tabular}{|c|c|}
\hline Welding current $(\mathrm{A})$ & Diameter of filler material $(\mathrm{mm})$ \\
\hline $1 \div 34$ & 1 \\
\hline $35 \div 42$ & 1,2 \\
\hline $43 \div 66$ & 1,6 \\
\hline $67 \div 90$ & 2 \\
\hline $91 \div 140$ & 2,4 \\
\hline $141 \div 300$ & 3 \\
\hline
\end{tabular}

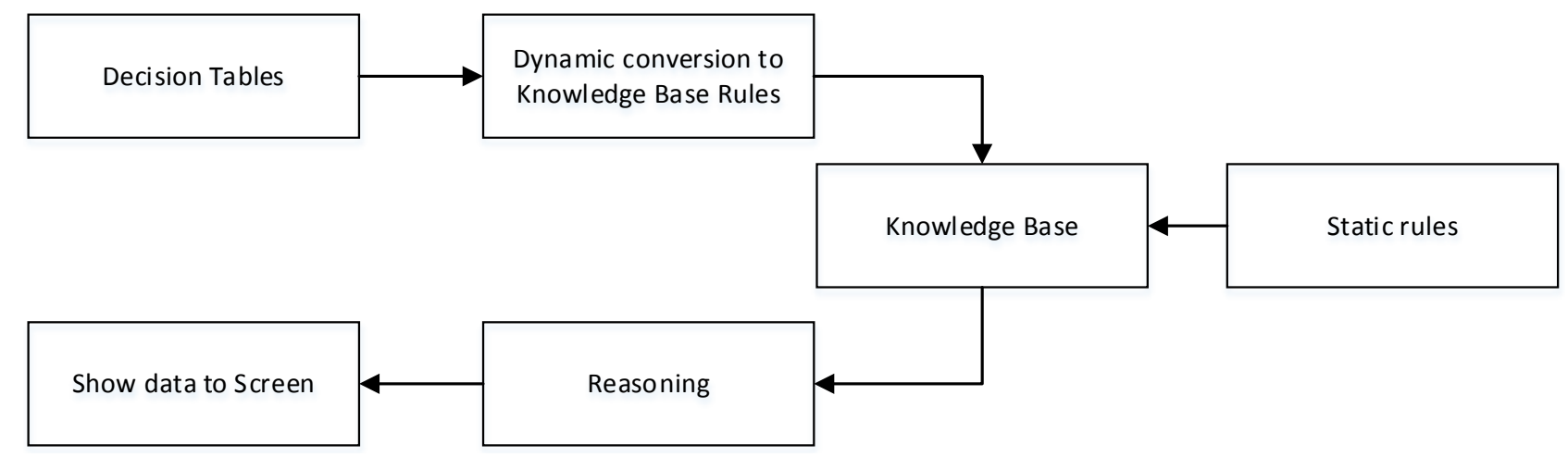

Figure 2 Expert System Model
Table 5 Diameter of the electrodes

\begin{tabular}{|c|c|}
\hline Welding current $(\mathrm{A})$ & Diameter of the electrodes $(\mathrm{mm})$ \\
\hline $1 \div 70$ & 1,6 \\
\hline $71 \div 150$ & 2,4 \\
\hline $151 \div 300$ & 3,2 \\
\hline
\end{tabular}

Type of gas: All values were set to "Ar 4.6".

Gas flow: All values were set to " $6 \div 8$ ".

Voltages: All values were set to "12" V.

A formula for heat input for determining the parameters limits in the calculation procedure is also applied [14].

$Q=\frac{U \cdot I \cdot 60}{v} \cdot k \cdot \frac{1}{1000} \mathrm{~kJ} / \mathrm{cm}$

Where: $U$ - Voltage (V), I - Welding current (A), vWelding speed $(\mathrm{cm} / \mathrm{min}), k$ - Efficiency of welding process $(k=0,6$ for TIG).

\subsection{Calculating the welding time}

The final calculation of the welding time is based on mathematical formula with the following parameters [15]: $t$-Welding time (result) (min), $l$ - Length of weld (mm) $w$ - Number of welds $(-), v-$ Welding speed $(\mathrm{cm} / \mathrm{min}), p$ - Welding position factor (-), $P$ - Preparation time (min).

$t=\frac{l \cdot w \cdot p}{10 \cdot v}+P \min$

The result is the welding time in minutes.

\subsection{Expert system model}

The proposed method of calculating welding time is based on the knowledge base that presents the knowledge concept and uses two types of rules:

a) dynamic rules derived from decision making tables that can vary in the course of operation of the system;

b) predefined static rules (i.e. a rule that defines the formula to calculate the welding time).

Fig. 2 shows the data flow of the expert system. 
In the first step, decision tables are transformed to the knowledge base rules form. At the next step, generated rules are merged to the predefined (static) rules where they become part of the knowledge base. Then follows the reasoning and showing data to the user's screen.

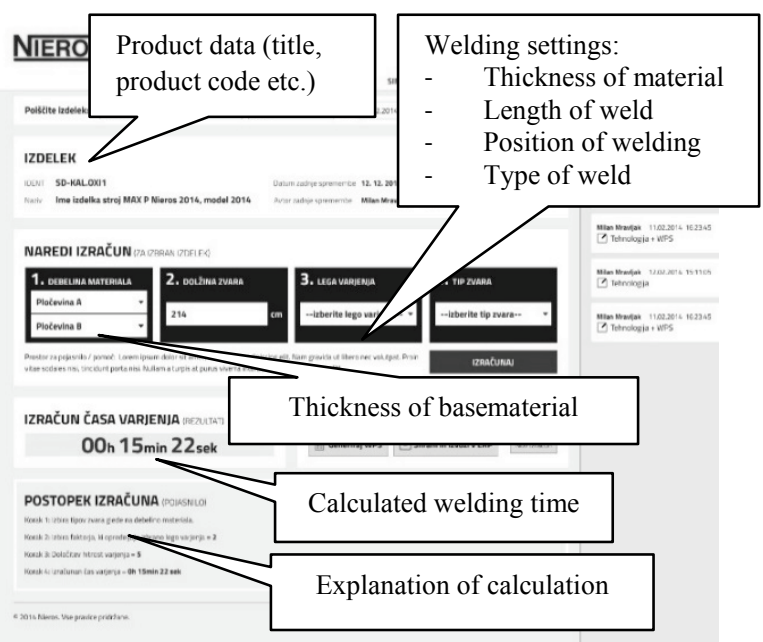

Figure 3 ESV - Expert System of Calculating Welding time

\section{Practical application}

Application of ESV (Expert System for Calculation of Welding Time) is a pilot project for an advanced implementation of the knowledge management system in the field of welding executed in the Nieros metal d.o.o. company. It also indicated further development of the information system in the company. The ESV's main function is calculating the welding time that is accessible to users in various ways. From the user's point of view, the applications support three groups of users:

- Unknown user: providing user the ability to use undeclared applications of an ESV for the purposes of verifying the welding time calculations, such as for learning.
- $\quad$ Engineer (Fig. 3): using application that is integrated with company's ERP system. The ERP system will redirect itself to a certain stage in the application that calculates the welding time and produces the WPS document.

- Application administrator: System Administrator will have the appropriate rights to edit code and review application's logs.

\subsection{Ontology}

An ontology describing the necessary knowledge for the calculation of welding time represents the main part of the expert system. It is implemented with the OWL language, which is one of the languages for the representation of knowledge with semantic technologies [16][17]. Ontology contains the following entities (Fig. 4):

- Metal: defining the material dimension,

- Weld: defining type of weld for a specific welding purpose,

- Quality of material: defining the quality of metal,

- The position of the welding: defining the position of welder,

- $\quad$ Properties of welding: defining properties of welding (i.e. welding speed, gas, welding current, diameter of filler material, diameter of welding nozzle, number of welds etc.).

Rules for reasoning are also a part of the ontology.

There are two groups of rules:

- Static rules: defined in advance and set out to knowledge worker. For example, rule defining the relationships between the entities and rule defining the formula for calculating the welding time.

- Dynamic rules: generated automatically, depending on the input to the application and intended to display ontologies with instances. They are generated from decision tables.
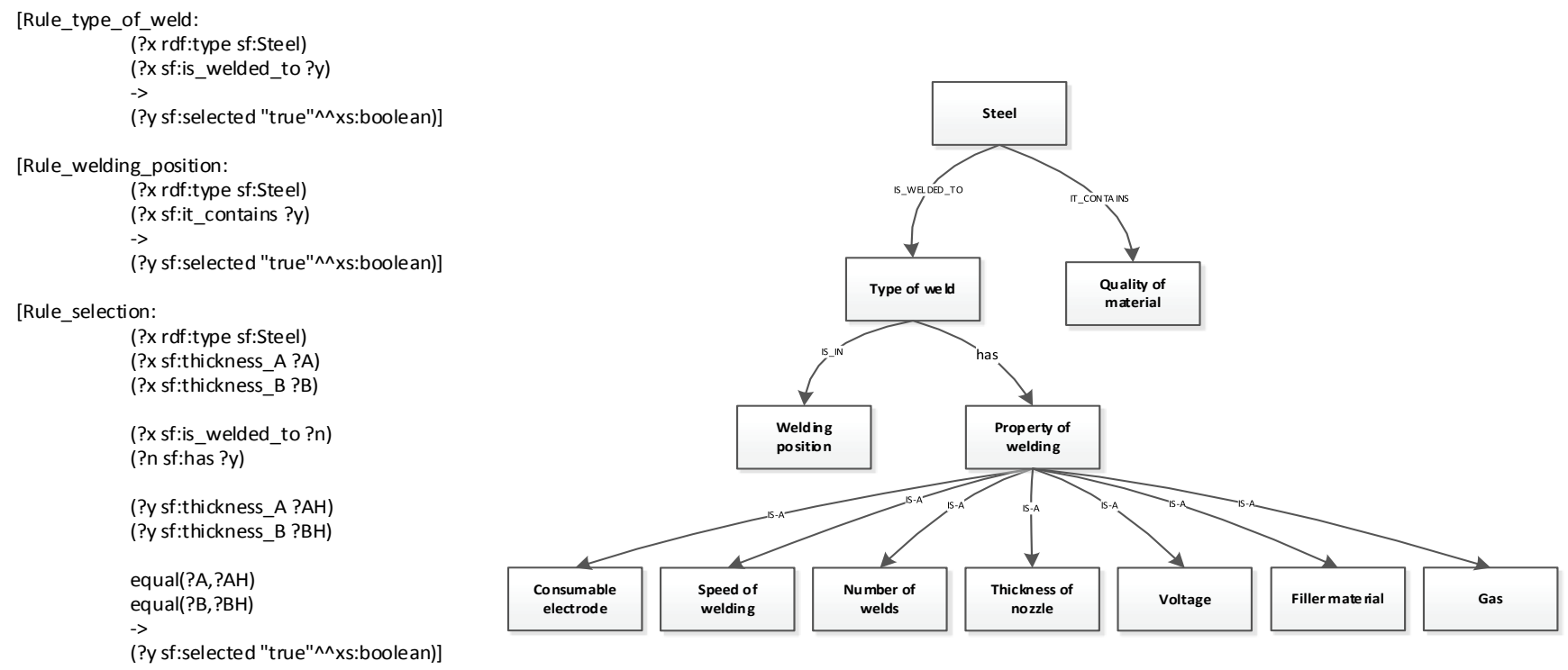

Figure 4 Welding Ontology 


\subsection{System architecture}

The expert system implementation is based on DotNetNuke CMS platform and uses C\# .NET programming language. There is an additional API
Jena.NET implemented and included to the system for working with ontologies and reasoning purposes [18]. Fig. 5 shows architecture of the whole system.

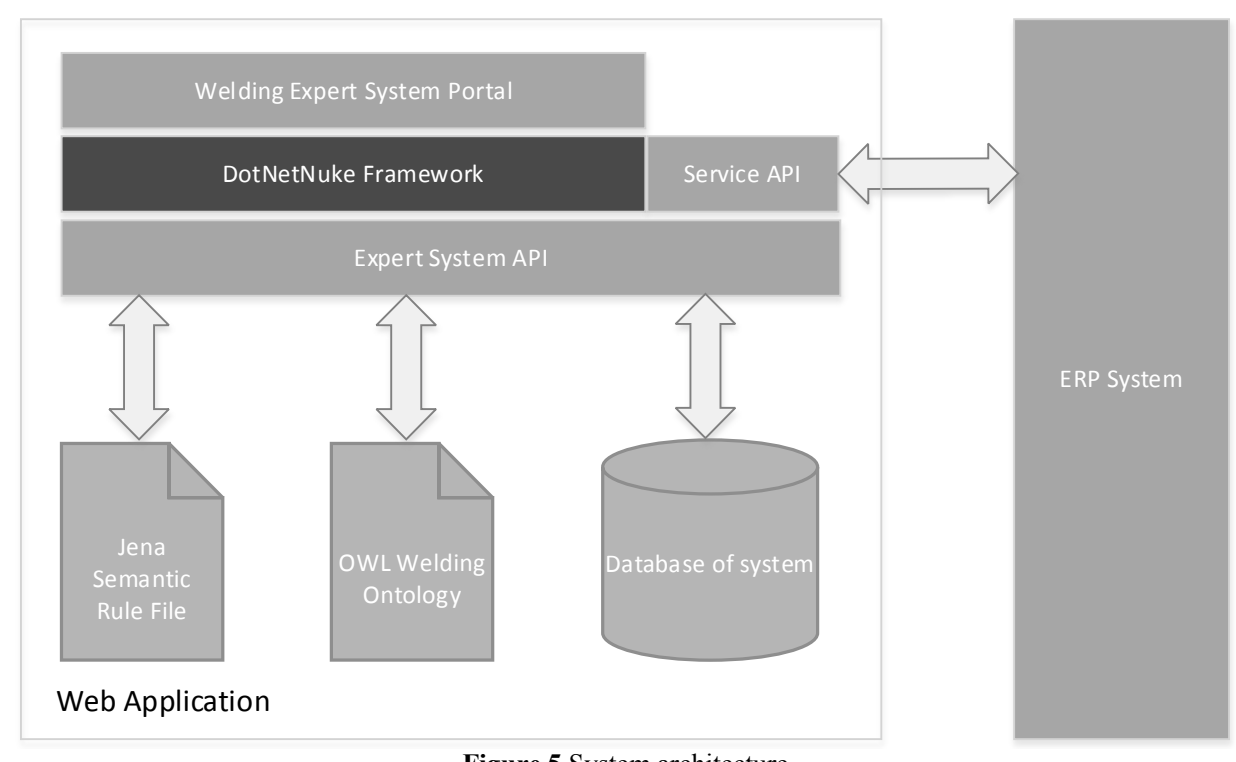

Figure 5 System architecture

The system architecture is a classical 3-tier, implemented as DotNetNuke portal module. There is presentation logic on the user interface layer containing user controls and other logic for user interface. Business logic with different operations classes (such as calculations) is very important for correct operation of the whole system and consequently, it is incorporated on the second level. Expert System API (implementation of proposed method) using Jena.NET library for operation is included on the same level [18]. On the same level, we also implemented integration with the ERP system of the Nieros Metal d.o.o. company, using web service technology. On the bottom, there is a data layer containing relation databases of the portal, welding ontology and files with semantic rules of welding ontology.

\subsection{Experiment}

An experimental verification of the proposed method was divided into two parts. The first one was a comparison of the calculated times of welding with the actual times achieved in production processes. In this experiment, we used data calculations of past two years (261 368 welding calculations) in combination with the entire history of the calculations referred to in EPR system of the company available. The application (ESV) was redesigned in a way that it extracts all the information necessary for the calculation of welding times from the ERP system and saves results in the log.

The second part of the method was a comparison of the calculated welding times with the welding times determined by engineers at the design stage. In this experiment, there were nine engineers (3 trainee engineers, 4 engineers with experiences, 2 experts). For the purposes of the experiment, we implemented the calculation of welding times with the application, although previous knowledge was not available. This application was then integrated with the company's ERP system; calculations were performed in the background during welding and the results were stored in the log.

\begin{tabular}{|c|c|c|c|c|c|c|}
\hline $\begin{array}{c}\text { Material } \\
\text { A }\end{array}$ & $\begin{array}{c}\text { Material } \\
\text { B }\end{array}$ & $\begin{array}{l}\text { Type } \\
\text { of } \\
\text { weld }\end{array}$ & $\begin{array}{l}\text { Length } \\
\text { of weld }\end{array}$ & $\begin{array}{c}\text { Position } \\
\text { of } \\
\text { welding }\end{array}$ & $\begin{array}{l}\text { Welding } \\
\text { time }\end{array}$ & $\begin{array}{c}\text { Calculated } \\
\text { welding } \\
\text { time }\end{array}$ \\
\hline $0,8 \mathrm{~mm}$ & $11 \mathrm{~mm}$ & S-I & $\begin{array}{c}6000 \\
\mathrm{~mm}\end{array}$ & 1,5 & $\begin{array}{c}23 \mathrm{~min} \\
05 \mathrm{sec}\end{array}$ & $\begin{array}{c}24 \min 39 \\
\mathrm{sec}\end{array}$ \\
\hline $5 \mathrm{~mm}$ & $6 \mathrm{~mm}$ & S-X & $\begin{array}{c}9000 \\
\mathrm{~mm}\end{array}$ & 1 & $\begin{array}{l}59 \mathrm{~min} \\
26 \mathrm{sec}\end{array}$ & $\begin{array}{c}1 \mathrm{~h} 05 \mathrm{~min} \\
12 \mathrm{sec}\end{array}$ \\
\hline$\ldots$ & & & & & & \\
\hline
\end{tabular}

The whole experiment was repeated using the values in the decision tables that are defined in the welding standards.

In this experiment, it was most important that the calculated welding times are very close to the actual welding times.

\section{Results}

In the first part of the experiment, 261368 calculations and comparisons of the calculations were conducted. A comparison of actual welding times and proposed welding times, calculated by the expert system, was carried out. For an exact result, a deviation from the real result to $\pm 15 \%$ was set. The results were as follows:

Table 7 Comparison real time vs. expert system

\begin{tabular}{|c|c|c|}
\hline Shorter & Correct & Longer \\
\hline $22 \%$ & $74 \%$ & $4 \%$ \\
\hline
\end{tabular}

The results of the first part of experiment using the value of the welding standard in decision tables are shown in the table below. 
Table 8 Comparison real time vs. expert system using values of welding standard

\begin{tabular}{|c|c|c|}
\hline Shorter & Correct & Longer \\
\hline $29 \%$ & $52 \%$ & $19 \%$ \\
\hline
\end{tabular}

A graphical presentation of second part of experiment is shown in Fig. 6.

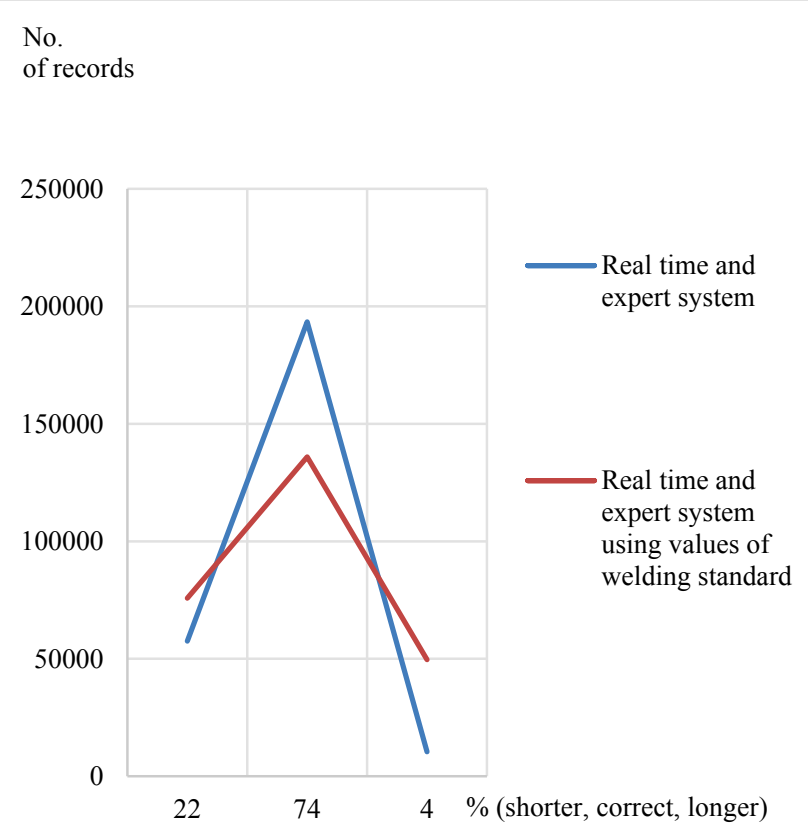

Figure 6 Graphical presentation of results of the first experiment (Tab. 7 and Tab. 8)

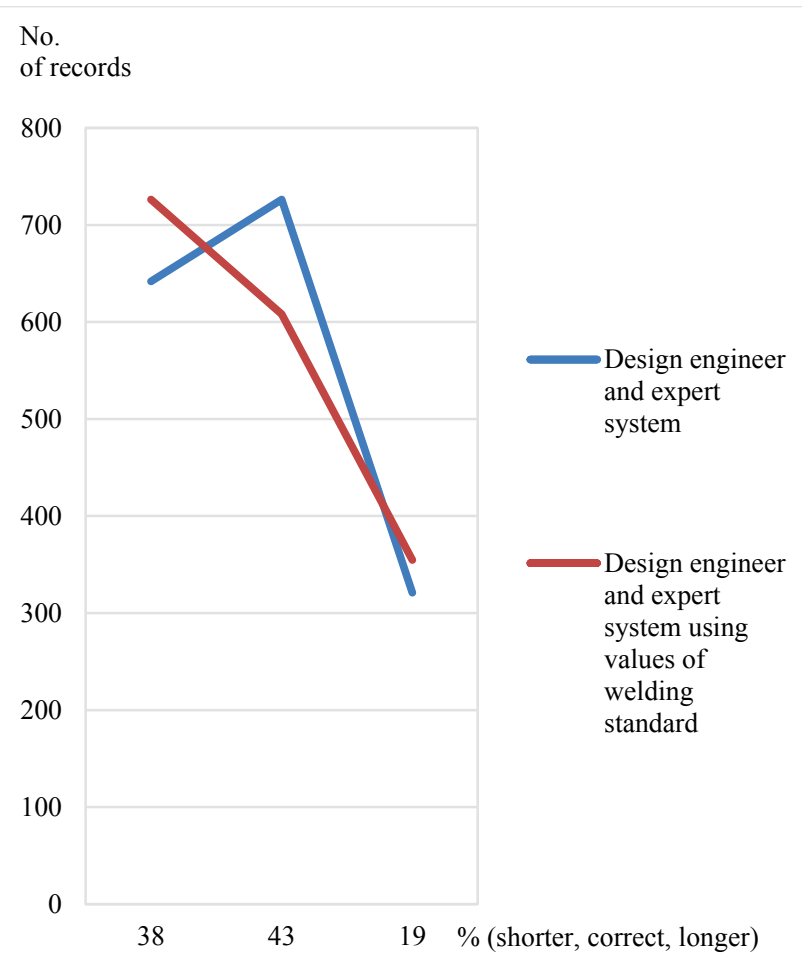

Figure 7 Graphical presentation of results of the second experiment (Tab. 9 and Tab. 10)

The second part of the experiment was to compare the welding time from the conceptual phase with welding time determined by an expert (design engineer) and welding time calculated by the expert system. 1689 calculations were performed. The results were as follows:
Table 9 Comparison design engineer vs. expert system

\begin{tabular}{|c|c|c|}
\hline Shorter & Correct & Longer \\
\hline $38 \%$ & $43 \%$ & $19 \%$ \\
\hline
\end{tabular}

The results of the second part of the experiment using the value of the welding standard in decision tables are shown in the table below.

Table 10 Comparison design engineer vs. expert system using values of

\begin{tabular}{|c|c|c|}
\hline \multicolumn{3}{|c|}{ welding standard } \\
\hline Shorter & Correct & Longer \\
\hline $43 \%$ & $36 \%$ & $21 \%$ \\
\hline
\end{tabular}

A graphical representation of the second part of experiment is shown in Fig. 7.

\section{Discussion}

The entire experiment focused on verifying the proposed approach for calculation of welding times. The experiment shows that welding times calculations are very close to the actual welding times. Considering that, the calculation of the time needed in the conceptual stage of welding marginally deviates from the real welding time. The percentage of success of our approach was very high, $74 \%$ (see Tab. 3). Less successful was the calculation of welding time using the values from decision tables from the welding process standard, but the end result was still sufficient (see Tab. 4).

The second part of our experiment focused on the comparison between design engineer and our expert system. The results were as expected: the matching of calculated welding times was very low (see Tab. 5 and Tab. 6). The reason for this deviation is a huge difference in the expertise of design engineers that greatly affects the calculation of welding times.

However, the reason for better results of our proposed approach is in the formula for calculating welding times that also contains the preparation time (see Chapter 3.2). Namely, the preparation time is specified in the Nieros metal d.o.o.'s internal welding standard. Value of the preparation times depends on the following parameters:

- Material (geometry of material, time of material preparation)

- Type of weld (welding passes, pipes, etc.)

- Skills of welder (i.e. beginner, senior, etc.).

For every product in the design phase, the planning expert specifies parameters in the ERP system.

The second reason for better results is the usage of parameters from decision tables. Parameters and rules for calculating are accommodated to the used technologies and business processes in the Nieros metal d.o.o. company.

From the technological point of view, the implementation of the proposed approach with Semantic Web technologies proved very useful. Any changes in the logic are simply realizable and upgradeable to a larger system (e.g. knowledge portal to support the new product development).

It is our opinion that the disadvantage of the proposed approach lies in its knowledge base, which entirely depends on the knowledge worker. There is no support for 
automatic calculation of values in the decision tables and there is no support for calculating welding times for pipes.

However, the main goals of the application and our approach that were set and met are:

- proposing calculated welding times for planning purposes;

- generating draft WPS document (not a final document);

- performing a pilot project for gathering expert knowledge (particularly for IT technology and organization used in developing further expert systems).

\section{Conclusion}

In this paper, we introduced our approach for calculation of welding times using Semantic Web technologies. The approach was performed and analysed for the specific case of calculating welding times in the Nieros Metal d.o.o. Company. The results of experiment described in this paper show the good performance of our approach, but also some limits and disadvantages.

In the future work we will address the limits of the proposed approach:

- $\quad$ support to e-learning for new welding engineers (knowledge base);

- $\quad$ support to recalculating decision tables values;

- knowledge extraction for welding knowledge base from web and from the company's internal documents (standards);

- $\quad$ upgrading the whole expert system to knowledge portal for product development.

\section{Acknowledgements}

We would like to thank the Nieros metal d.o.o. for their support during development and testing of Expert System for Calculation of Welding Time.

\section{References}

[1] Shortliffe, E. H.; Axline, S. G.; Buchanan, B. G.; Merigan, T. C.; Cohen, S. N. An Artificial Intelligence program to advice physicians regarding antimicrobial therapy. // Computers and Biomedical Research. 6, 6(1973), pp. 544560. https://doi.org/10.1016/0010-4809(73)90029-3

[2] Berners-Lee, T. Putting the Web back into Semantic Web, ISWC2005 Keynote, http://www.w3.org/2005/Talks/1110iswc-tbl (19.2.2016)

[3] Mohammadhassanzadeh, M.; Van Woensel, W.; Abidi, S. R. A semantic web-based approach to plausible reasoning for improving clinical knowledge engineering. // IEEEEMBS International Conference on Biomedical and Health Informatics (BHI), 2016. https://doi.org/10.1109/BHI.2016.7455950

[4] Mathialakan, T.; Hoole, H.; Ratanajeevan, S. Expert System and Semantic Web Knowledge Base for Low Frequency Electromagnetic Devices. // Journal of Computational Intelligence and Electronic Systems. 3, 4(2014), pp. 312-316. https://doi.org/10.1166/jcies.2014.1104

[5] Muñoz, A.; Lasheras, J.; Capel, A.; Cantabella, M.; Caballero, A. OntoSakai: On the optimization of a Learning Management System using semantics and user profiling. // Expert Systems with Applications, Elsevier. 42, 1516(2015), pp. 5995-6007.
[6] Verhodubs, O.; Grandspenkis, J. Towards the Semantic Web Expert System. // Scientific Journal of Riga Technical University. 44, 1(2011), pp. 116-123. https://doi.org/10.2478/v10143-011-0029-y

[7] Tsoukalas, V.; Kontesis, M.; Badogiannis, E.; Papachristos, D.; Fragiadakis, N. Prototype of an expert system for aluminum welding. // CIMMACS'06 Proceedings of the 5th WSEAS International Conference on Computational Intelligence, Man-Machine Systems and Cybernetics. (2006), pp 78-83

[8] Lina, H. K.; Harding, J. A. A manufacturing system engineering ontology model on the semantic web for interenterprise collaboration. // Computers in Industry. 58, 5(2007), pp. 428-437. https://doi.org/10.1016/j.compind.2006.09.015

[9] Chen, Yuh-Jen; Chen, Yuh-Min; Chu, Hui-Chuan. Development of a mechanism for ontology-based product lifecycle knowledge integration. // Expert Systems with Applications: An International Journal. 36, 2(2009), pp. 2759-2779. https://doi.org/10.1016/j.eswa.2008.01.049

[10] Panetto, H.; Dassisti, M.; Tursi, A. ONTO-PDM: Productdriven ONTOlogy for Product Data Management interoperability within manufacturing process environment. // Advanced Engineering Informatics, Elsevier. 26, 2(2012), pp. 334-348. https://doi.org/10.1016/j.aei.2011.12.002

[11] Baloh, P.; Vasić, V.; Desouza, C.; Stropnik, A. Application of KM Technology in development of new multifunctional products. // Knowledge Management in Organizations, Maribor. (2006), pp. 75-81.

[12] Urrea, C.; Henríquez, G.; Jamett, M. Development of an expert system to select materials for the main structure of a transfer crane designed for disabled people. // Expert Systems with Applications, Elsevier. 42, 1(2015), pp. 691697. https://doi.org/10.1016/j.eswa.2014.08.017

[13] Janasekaran, S.; Yusof, F.; Zin, H. M.; Jamaludin, M. F.; Shukor, M. H. A. A fuzzy logic-based prediction model for fracture force using low-power fiber laser beam welding. // The International Journal ofAdvanced Manufacturing Technology, Springer. (2017), pp. 1-8.

[14] Rak, I. Tehnologija varjenja, Modrijan, Maribor, (2008).

[15] Tomšič, J.; Šteharnik, T. Procesi varjenja, Nieros metal d.o.o., Internal report, (2013).

[16] Heflin, J. OWL 2 Web Ontology Language Document Overview (Second Edition). http://www.w3.org/TR/owl2overview (12. 8. 2016)

[17] Yadav, U.; Narula, G. S.; Duhan, N.; Jain, V.; Murthy, B. K. Development and Visualization of Domain Specific Ontology using Protégé. // Indian Journal of Science and Technology. 9, 16(2016), pp. 1-7. https://doi.org/10.17485/ijst/2016/v9i16/88524

[18] Jena.NET - Flexible .NET port of the Jena semantic web toolkit, http://semanticweb.org/wiki/Jena_html (26.10.2016) 


\section{Authors' addresses}

Ambrož Stropnik

KiviCOM d.o.o.

Kidričeva 3a, 2380 Slovenj Gradec, Slovenia

ambroz@kivi.si

Tomaž, Vuherer, Dr. Sc.

Faculty of Mechanical Engineering, University of Maribor

Smetanova 17, SI-2000, Maribor, Slovenia

tomaz.vuherer@um.si

Ivan Samardžić, Dr. Sc.

Mechanical Engineering Faculty in Slavonski Brod

J. J. Strossmayer University of Osijek

Trg Ivane Brlić-Mažuranić 2

35000 Slavonski Brod, Croatia

Milan Zorman, Dr. Sc.

Faculty of Electrical Engineering and Computer Science,

University of Maribor

Smetanova 17, SI-2000, Maribor, Slovenia

milan.zorman@um.si 